\title{
DEMOCRACIA GREGA: A ANTIGA ATENAS (SÉC. V a. C.)
}

\author{
GREEK DEMOCRACY: THE ANCIENT ATHENS (V BC.)
}

Maria Dulce Reis*

\section{RESUMO}

Para compreendermos a democracia grega, em particular o caso ateniense, ele deve ser situado historicamente, pois suas condições de surgimento e sua estruturação política tiveram uma determinação histórica e somente nela encontram o sentido de sua ocorrência. As fontes de que dispomos hoje são os textos de historiadores e de filósofos antigos, bem como de estudiosos contemporâneos do tema. O presente texto aborda as fontes e significados da temática no século $\mathrm{V}$ a. C. (democracia, cidade), a historicidade do surgimento da democracia ateniense (Clístenes; Péricles), os componentes da democracia ateniense (valores, instituições), o olhar da filosofia de Platão sobre a democracia (República, Leis), convidando o leitor a não julgar as fontes históricas e a experiência democrática grega e, sim, a buscar compreendê-las.

PALAVRAS-CHAVE: Democracia grega. Democracia ateniense. Filosofia Antiga.

\section{ABSTRACT}

To understand Greek democracy, mainly in the Athenian case, it must be historically situated, since its conditions of appearance and political structure had a factual determination, and only in itself we find the meaning of its occurrence. The sources we have today are texts of historians and ancient philosophers, as well as texts from contemporary experts of the subject.The present text addresses sources and meanings of the thematic in the fifth century a. C. (democracy, city), the historicity of Athenian democracy emergence (Clístenes, Pericles), the components of Athenian democracy (values, institutions), the look of Plato's philosophy on democracy (Republic, Laws), inviting the reader to not judge the historical sources and the Greek democratic experience, but trying to understand them.

KEY WORDS: Greek democracy. Athenian democracy. Ancient Philosophy.

\section{FONTES E SIGNIFICADOS NO SÉCULO V a. C. (DEMOCRACIA, PÓLIS)}

Para compreendermos a democracia grega, em particular o caso ateniense, este deve ser situado historicamente, pois suas condições de surgimento e sua estruturação política tiveram uma determinação histórica e somente nela encontram o sentido de sua ocorrência. As fontes de que dispomos hoje são os textos de historiadores e de filósofos antigos, bem como de estudiosos contemporâneos do tema.

Comecemos pela terminologia. O termo demokratía aparece em obras dos historiadores Heródoto (484 a.C - 425 a.C) e Tucídides (460 a. C. - 395 a. C.), bem como na

\footnotetext{
* Doutora em Filosofia pela UFMG. Professora de Filosofia no Departamento de Filosofia da PUC Minas. Email: mariadulcereis@ pucminas.br.
} 
obra de filósofos como Platão (República) e Aristóteles (Política). Nelas, é referida como governo exercido pelo dêmos (povo, conjunto de cidadãos livres) ${ }^{1}$, ou como governo exercido pelos pobres (em contraposição a demais classes) (FERREIRA, 1989; PEREIRA, 1993). Pereira (1993), tomando como fontes Heródoto e o Xenofonte das Memoráveis, esclarece que esse grupo da população correspondia à classe dos "pequenos comerciantes, marinheiros, lavradores, artesãos” (p. 180), o que excluía mulheres, estrangeiros e escravos. Finley (1988, p. 29) relata que grande parte dos cidadãos correspondia "aos camponeses, comerciantes e artesãos, que eram cidadãos lado a lado com os instruídos das classes mais altas". Ferreira (1989, p. 178-179) indica que a maioria dos cidadãos era constituída por "pequenos comerciantes, camponeses, artesãos, marinheiros ou mesmo simples assalariados".

Após a Antiguidade, a ocorrência do termo democracia interrompe-se, ressurgindo no século XVIII (PEREIRA, 1993; SARTORI, 1994; HANSEN, 1992). Quanto ao significado e ao exercício da democracia, vale a observação de Robert Dahl (2001, p. 13) de que "democracia tem significados diferentes para povos diferentes em diferentes tempos e diferentes lugares". Essas diferenças devem ser identificadas quando se deseja comparar ocorrências da democracia em locais ou épocas distintas.

Condições favoráveis à participação popular no governo que, segundo Dahl (2001, p. 20), seriam "a identidade do grupo, a pouca interferência exterior, um pressuposto de igualdade" podem ter ocorrido em diferentes locais na Antiguidade, contudo "os sistemas de governo que permitiam a participação popular de um significativo número de cidadãos foram estabelecidos pela primeira vez na Grécia clássica e em Roma, por volta do ano 500 a. C." (p.21), ressalvando-se suas diferenças ${ }^{2}$.

\footnotetext{
${ }^{1}$ Segundo o Le Grand Dictionnaire Grec Français de Anatole Bailly (p. 457-458), o termo dêmos ocorre 1) com ideia de lugar (como terra habitada por um povo); 2) no sentido político (como cidadãos livres participantes de um governo democrático); 3) no sentido de raça (grupo, gênero); 4) referindo-se a uma pessoa (o cidadão). $\mathrm{O}$ autor cita as ocorrências de tais sentidos em textos da cultura grega antiga. Quanto ao significado de "pobres", ele pode ser encontrado em citações de Platão (República XVIII 557a) e de Aristóteles (Política III 1275; 1279; 1280), abrangendo uma camada dos cidadãos livres. Aristóteles contrapõe democracia e oligarquia em razão da posse ou não de riquezas: "Onde quer que os homens governem devido à sua riqueza, sejam eles poucos ou muitos, há uma oligarquia, e onde os pobres governem, há uma democracia" (Política III 1279b - 1280a). Conforme o estudo de Hansen (1992, p. 14), Tucídides referiu-se à democracia como "governo da maioria" na Oração Fúnebre dedicada a Péricles. Para o presente texto, não fizemos uma releitura das obras de Heródoto e Tucídides, retomando as contribuições de tais fontes históricas apenas e conforme suas referências pelos comentadores recentes.

${ }^{2}$ Conforme Dahl (2001, p. 23-24), “mais ou menos na época em que foi introduzido na Grécia, o governo popular apareceu na península italiana na cidade de Roma. Os romanos preferiram chamar seu sistema de república: res, que em latim significa coisa ou negócios, e publicus... O direito de participar no governo da república inicialmente estava restrito aos patrícios, os aristocratas. [...] depois de muita luta, o povo (a plebe) também adquiriu esse direito. [...] por volta do ano 130 a. C. ela começou a enfraquecer... perecendo com a
} 
Quanto à Grécia clássica (séc. V a IV a. C.), a literatura a que tivemos acesso nos oferece mais dados sobre a democracia na pólis de Atenas, ainda que sua ocorrência com formatos distintos tenha se verificado em outras cidades gregas, como Delfos, Cirene, Siracusa, Éfeso, dentre outras (HANSEN, 1992; ARNAOUTOGLOU, 2003; MCWHORTER, 1951) ${ }^{3}$. Aristóteles, no quinto livro da Política, cita as cidades de Cos, Rodes, Heracleia, Megara e Cumes como cidades que tiveram seu regime democrático derrubado pela ação de demagogos (1304b 25 - 1305a 5) e menciona as cidades de Siracusa, Cálcis e Ambrácia como cidades em que o povo mobilizou a transformação de seus regimes políticos em democracia (1304a 25-30).

Pólis é melhor traduzida como "cidade" e quando é referida a "cidade-estado" não deve ser compreendida como a concepção moderna de Estado, a qual pressupõe uma unidade política soberana que se impõe sobre uma sociedade, regida por uma constituição (SARTORI, 1994, p. 35) ${ }^{4}$. A Grécia era composta por centenas de cidades independentes, ainda que tenha ocorrido a formação de algumas alianças para defesa comum (DAHL, 2001, p. 21-22). Numa cidade grega com composição democrática, o conjunto daqueles ali considerados cidadãos participa diretamente da formulação e execução tanto da legislação, como de decisões políticas e jurídicas. Sartori (1994) nos lembra que "a pólis era uma cidade-comunidade, uma koinonía. Tucídides definiu-a com três palavras: ándres gar pólis - os homens é que são a cidade. É muito revelador que politeia tenha significado, ao mesmo tempo, cidadania e estrutura (forma) da pólis" (p. 35). Isso se confirma em Aristóteles (Política III 1275b 15-20) quando considera que, numa democracia, “o cidadão é aquele que tem uma parte legal na autoridade deliberativa e na autoridade judiciária" (ARISTÓTELES, 2010, p. 54). Os cidadãos, em sua participação direta, constituíam o sustentáculo da estrutura da pólis democrática e a condição dos não cidadãos colaborava para a manutenção de tal estrutura, como detalharemos adiante.

\footnotetext{
ditadura de Júlio César. Depois de seu assassinato em 44 a. C. [...] tornou-se um império comandado por imperadores".

${ }^{3}$ Os nomes das cidades mencionados acima foram inferidos dos três estudos citados. Contudo, nenhum desses estudos traz com clareza uma listagem de cidades que teriam vivenciado o regime democrático. "As more and more power passed from Council to the general Assembly, oligarchy was succeeded by democracy; sometimes in the transition it was was followed by tyranny. [...] Democracy, the rule of Dêmos, or the people, had in ancient Greece many successes and many reverses. Some of the Ionian states experimented early with this form, and after the defeat of Sparta by Thebes in 371 B. C. many of the Dorian oligarchies gave way to democracies. Popular government, however, prevailed successfully only at Athens..." (MCWHORTER, 1951, p. 291).

${ }^{4}$ Vale notarmos que são latinos os termos Estado (derivado do particípio passado latino status) e República (coisa pública); a respeito, ver Sartori (1994, p. 46-47), bem como Dahl (2001, p. 21-35).
} 
O pesquisador ateniense contemporâneo Ilias Arnaoutoglou (2003) produziu um compêndio bastante significativo com a seleção de várias leis de cidades gregas antigas que nos permite vislumbrar um pouco do que teria sido normatizado em suas práticas democráticas. $\mathrm{O}$ autor apresenta legislações de âmbito público e doméstico das cidades de Delfos e Atenas na Grécia continental, Gortina em Creta, Ólbia no sul da Rússia, além de urbes do Egeu, inclusive Éfeso, Samos e Tasos. Dado que "as póleis gregas antigas não eram só comunidades políticas, eram também comunidades religiosas" (p. XXXI), havia leis sobre tais atividades nas cidades, bem como sobre diplomacia, deveres públicos, constituição, delitos, dentre outros temas. Citaremos exemplos de algumas dessas legislações oportunamente.

\section{HISTORICIDADE DO SURGIMENTO DA DEMOCRACIA ATENIENSE (CLÍSTENES; PÉRICLES)}

Passemos ao período histórico. A Atenas de fins do século VI a. C., grande parte do século V a. C. e do século IV a. C., foi uma cidade democrática, ainda que intercalada com breves períodos de regimes oligárquicos, dotada de pequena população, pequeno território ${ }^{5}$. $\mathrm{O}$ presente artigo limita-se a referir-se ao século V a. C. ateniense, momento da consolidação do regime democrático, de suas instituições e valores, da participação política direta dos cidadãos, reconhecidos como tais por serem filhos de pais atenienses e habitantes de uma das dez tribos ou regiões geográficas, assim delimitadas por Clístenes e mantidas por Péricles. Tratemos destes.

Não vamos nos ater às condições históricas que antecedem o período do governo ateniense de Clístenes, pois intencionamos apenas buscar identificar as características da democracia ateniense em seu período áureo, nos governos de Clístenes e de Péricles.

Clístenes é eleito arconte em fins do século VI a. C. e empreende as reformas administrativas e políticas que democratizaram Atenas, posteriormente à tirania de Psístrato e também de Híppias.

Conforme nos esclarece o recente estudo de Bruno D’Ambros (2017, p. 97-98):

\footnotetext{
${ }^{5}$ Reconhecemos a contribuição de Sólon para Atenas (início do século VI a. C.), pela criação de leis e instituições, como a própria Assembleia. Aqui, contudo, a participação dos cidadãos ocorria por divisão territorial feita segundo sua renda: trabalhadores, hoplitas, cavaleiros, possuidores de renda elevada (BIGNOTTO, 1998, p. 28), o que se perderá com a tirania de Psístrato (561 a. C.). Ver também Reis; Oliveira (2009).
} 
O principal evento para a consolidação da democracia, além das reformas anteriores de Sólon e dos Pisistrátidas, foi, sem dúvida a reforma territorial sob Clístenes, ocorrida por volta de 508 a. C. Foi esta reforma que, ao reconfigurar a demografia ática, enfraqueceu os laços parentais das famílias aristocráticas áticas e possibilitou a participação política efetiva nas eleições e nas instituições democráticas atenienses. O que houve, em outros termos, foi que os novos dēmoi nascentes, como nova divisão territorial administrativa, se contrapôs com a divisão familiar tradicional de parentesco denominada genos, o que contribuiu para a exacerbação da antítese entre uma aristocracia familiar local estabelecida e uma democracia política translocal introduzida. [...] Clístenes tomou uma série de medidas reformatórias, principalmente no que tange à reorganização política do território da Ática mudando a organização política ateniense, que era baseada em quatro tradicionais tribos com fortes laços de parentesco entre si, que foram responsáveis pelas tiranias anteriores. A fim de impedir que a tirania se instalasse novamente através destas relações de parentesco, Clístenes dividiu a Ática em dez tribos de acordo com sua área de residência, o seu dêmos.

A abertura política proporcionada pelo governo de Clístenes à participação direta dos cidadãos conforme cada região geográfica - não mais conforme a uma nobreza "de sangue" 6 ancorada em crenças mítico-religiosas - traz uma descentralização do poder, mudanças políticas e também formativas (o que hoje chamaríamos de sócio-pedagógicas). Peixoto (1994) ressalta a importância da educação dos jovens filhos de comerciantes promovida a essa época por sofistas que lhes ensinavam a arte da retórica ${ }^{7}$, de modo a capacitar tais jovens para defenderem ideias e projetos na Assembleia dos cidadãos.

Clístenes setoriza a Ática em três regiões, por sua vez divididas em dez tribos, as trinta tritías, "que englobavam certo número de dêmos", unindo "distritos urbanos, rurais e costeiros" de modo a "solucionar os conflitos parental-aristocráticos entre as diversas facções e partidos", conforme D'Ambros (2017, p. 112), que ainda nos esclarece sobre os interesses políticos de Clístenes ao ceder participação política aos dèmoi:

Inspirado no bem sucedido populismo precedente dos pisistrátidas, Clístenes toma medidas igualmente populistas para se manter no poder, desagradando, naturalmente, a classe aristocrática, da qual ele mesmo fazia parte. Dentre estas medidas, as principais foram duas, a reforma demográfica e a ampliação dos poderes da ekklesia. Heródoto (HERÓDOTO, Histórias, V, 66.2; 69.2) sublinha este caráter

\footnotetext{
${ }^{6}$ Ver o detalhamento feito por Bruno D'Ambros (2017, p. 100-102) a respeito das fratríai, unidades parentalaristocráticas áticas conforme o parentesco com algum herói.

${ }^{7}$ Por sua vez, a filosofia vai se enriquecer com o debate entre esses novos educadores e Sócrates. Como o Sócrates histórico não nos deixou nada escrito, temos um retrato de tais debates em diálogos escritos por Platão após a morte do mestre. Trata-se de temáticas políticas (natureza, leis, convenções, etc.), da formação dos cidadãos para a virtude (habilidade da retórica, estado de alma, etc.) e da linguagem (o discurso humano, o poder da palavra, etc.).

8 "Na mesma tritía havia vários dēmoi e se crê ter havido cerca de 140 dēmoi em toda a Ática. Cada tribo é composta por três tritías, a da costa, cidade e planície. Cada tritía foi nomeada segundo o dêmos dominante." (D`AMBROS, 2017, p. 102, n.6).
} 
oportunista das medidas de Clístenes e igualmente Aristóteles, quando diz que "Clístenes trouxe o povo para o seu lado cedendo o controle do Estado para o plethos (plebe)" (ARISTÓTELES, Constituição dos atenienses, 20.2). Portanto, apesar de Clístenes ser considerado o real fundador da primeira democracia na história, seus interesses não foram altruístas, mas permeados de interesses pessoais e aristocráticos ou, mais amenamente, uma "combinação de auto interesse e acuidade pública" (BUCKLEY, 2010, p. 120). Assim, a democracia ateniense nasce propriamente com Clístenes, em função de sua reforma demográfica do território Ático. Os principais motores destas reformas foram dois que se inter-relacionam: o problema da cidadania ateniense e o problema das unidades parental-aristocráticas. (p. 99).

O fato de o grupo que mais participava das decisões políticas, o dêmos urbano (Alcmeônidas), corresponder àquele de Clístenes, faz com que historiadores levantem a hipótese de que Clístenes teria tido a intenção de fundo de manter-se no poder, sustentando seus interesses pessoais e aristocráticos (hipótese de D’Ambros, 2017, p.112, apoiando-se em Buckley (2010) - estudo a que não tivemos acesso). Camponeses, artesãos, comerciantes, marinheiros são convidados à participação democrática. Contudo, nem todos irão deslocar-se diariamente ao local da Assembleia, para seus debates e decisões, ou ainda participar de outras instituições democráticas.

Outra hipótese - a de Bignotto (1998, p. 37) - é a de que Clístenes reforma e fortalece instituições democráticas já introduzidas por Sólon visto ter percebido a importância do apoio popular na sustentação de um regime político (mesmo o tirânico) e os riscos do surgimento da tirania quando da incorporação do dêmos à vida política, fazendo-se necessária a tomada de medidas para evitar-se a emergência de regimes tirânicos.

Dentre as reformas estruturais de Clístenes está: a reforma do tribunal da Helieia para seiscentos juízes por tribo (cidadãos maiores de trinta anos, por sorteio), a ampliação da Boulé (Conselho dos Prítanes) para cinquenta homens por tribo (agora segundo cada região geográfica, por um ano, por sorteio) os quais preparavam os projetos para a Eclésia, a Assembleia popular então composta por todos os cidadãos registrados no dêmos de origem, filhos de pai ateniense, maiores de dezoito anos. Também há a criação dos cargos de Estrategos (chefes militares, um por tribo) e a retomada da medida de "ostracismo" (banimento e cassação dos direitos políticos por dez anos, evitando-se as tiranias).

Não vamos nos deter aqui nos vários conflitos da época, entre interesses dos mais ricos e aqueles dos mais pobres e interesses políticos das diversas facções de então. Importa reconhecermos que se encontra fortalecido o poder dos cidadãos de decidirem o que deveria ser o melhor para o todo da cidade, o que fortalece o poder político da cidade como tal. 
Há um período entre Clístenes e Péricles representado por outros líderes, sobretudo pelo aristocrata Címon e o democrata Elfíates. Após o assassinato do democrata Elfíates, o Estratego Péricles assume o poder, representando amplas camadas do povo ateniense.

A liderança de Péricles ocorre de 461 a 429 a. C., período em que a Eclésia adquire amplos poderes, com funções legislativas e executivas, além da fiscalização dos magistrados. Péricles restringe o direito de cidadania somente aos filhos de pai e mãe atenienses (10\% da população). Exceto os Estrategos, todos os demais cargos passam a ser escolhidos por sorteio. Trata-se de um período de prosperidade econômica e cultural, de grandes construções públicas e apoio às artes. Não é à toa que Péricles é elogiado por Aristóteles, na Ética $a$ Nicômaco (VI, 5, 1140b 5-10) como homem dotado de discernimento (phrónesis), de capacidade de agir bem no âmbito da cidade, excelência que une saber teórico e saber prático. Pereira (1993, p. 390) nos lembra que "o século de Péricles tem a sua mais alta expressão na tragédia”. As tragédias eram apresentadas todos os anos nos grandes festivais dionisíacos, expressavam temas da história grega e os conflitos humanos imersos nesse éthos. Importante foi o papel das comédias de Aristófanes, da encenação das tragédias e, de modo geral, das festividades religiosas gregas para a democracia ateniense, o que não abordaremos, visto os limites do presente trabalho ${ }^{9}$. Vale atestarmos que a participação direta dos jovens cidadãos em funções legislativas e executivas abre espaço para os interesses de todas as camadas da população, criando-se condições para a manutenção de valores democráticos, buscando-se impedir o surgimento de tiranias.

O ano de 431/430 a. C. corresponde ao início da guerra do Peloponeso, que os autores costumam dividir em três fases até 404 a. C., quando ocorre uma diminuição significativa da população ateniense já na primeira fase, por causa de uma peste (um quinto da população, incluindo o próprio Péricles), bem como ao final da guerra, quando Esparta impõe a Atenas o governo oligárquico dos "trinta tiranos", marcado por perseguições e mortes de democratas, desrespeito aos direitos dos cidadãos. Contudo, em 403 a. C., o democrata Trasíbulo e seus partidários moderados (dentre eles, Ânito) derrubam o governo oligárquico dos "trinta tiranos". Em 399 a. C., Sócrates é condenado à morte durante a "democracia restaurada", tendo o democrata Ânito como um de seus três acusadores do crime de impiedade contra a cidade $^{10}$. Antes mesmo do governo dos Trinta Tiranos, outro abalo na manutenção do regime

\footnotetext{
${ }^{9}$ A respeito, ver o estudo de Pereira (1993, capítulo V).

${ }^{10}$ Sobre o contexto humano, ético-político e filosófico em torno da morte de Sócrates, ver Reis; Oliveira (2009).
} 
democrático ateniense ocorreu em 411 a. C., quando os aristocratas, liderados por Pisandro, tomam o poder (regime oligárquico), mas esse dura apenas quatro meses ("Tirania dos Quatrocentos"). Não vamos entrar em detalhes sobre todas as forças políticas internas e externas a Atenas e seus líderes que, em alguns momentos dessa segunda metade do século $\mathrm{V}$ a. C., abalaram e mesmo substituíram o regime democrático por regimes oligárquicos. Quanto a isso, recomendamos a obra de Finley (1988). Importa-nos reconhecer que o próprio modo de ser do regime democrático ateniense permitiu tais abalos, pois as decisões sobre os confrontos militares (expedições, punição por traição, anistia) eram objeto de debate e de deliberação pela Assembleia ${ }^{11}$.

Finley (1988, p.26) destaca, dentre as considerações que Aristóteles faz sobre a democracia, a de que o risco da democracia é o de um governo realizado "pelos" pobres transformar-se em um governo realizado "no interesse" dos pobres, pois os interesses deveriam ser comuns. Platão (República VIII-IX) considera que a democracia se encontra a um passo da tirania, o que discutiremos mais adiante. Passemos aos valores democráticos e à participação dos cidadãos e dos "não cidadãos" na democracia ateniense à época de Clístenes e Péricles $^{12}$.

\section{COMPONENTES DA DEMOCRACIA ATENIENSE (VALORES, INSTITUIÇÕES)}

Conforme identificamos sobretudo nos estudos de Finley (1988), Ferreira (1989) e Pereira (1993), o exercício da democracia ateniense à época de Clístenes e Péricles sustentou a seguinte estrutura:

\footnotetext{
${ }^{11}$ Assim, por exemplo, "em 411 a Assembleia veio a votar pela eliminação da democracia e um Conselho temporário de quatrocentos integrantes foi levado ao poder" (FINLEY, 1988, p. 143). Este autor nos relata (p. 139) que a peste matou um terço dos cidadãos em um período de quatro anos. McWhorter (1951, p. 297), nos mostra que o período democrático pós 411 é considerado como democracia decadente: “[...] a democracy rather more impatient of criticism and opposition than had been the state in the time of Pericles. Athens drifted along, complacent, and perhaps decadent, while a new and powerful and dangerous state was being formed in the North. Demosthenes [349] in fiery words warned against the dangers threatening from Macedonia and Philip."

${ }^{12}$ Furio Durando (2005, p. 40) menciona que em Esparta, grande rival de Atenas, havia diferenças substanciais nas estruturas políticas, sociais e econômicas; embora houvesse uma Assembleia de cidadãos espartanos de mais de 30 anos (a apellá), estes eram descendentes de guerreiros fundadores e ela era submetida a dois reis, portanto uma tendência imperialista. Já para McWhorter (1951, p. 291), "Sparta established its oligarchical, militaristic, totalitarian government firmly by dividing the royal power between two men, to whom was given only a limited amount of authority." Para Hansen (1992, p. 18; p. 27) os movimentos revolucionários do século XVIII tiveram como inspiração Roma, mais que a Grécia e, quanto a esta, Esparta, mais que Atenas. Ainda que se possa admitir uma similaridade de valores.
} 


\section{Valores:}

Isonomia: igualdade perante a lei, refere-se à igualdade de direitos dos cidadãos.

Isegoria: igualdade no falar, mesmo direito à expressão por qualquer cidadão.

Isocracia: igualdade no poder, mesma oportunidade de participação nas instituições democráticas e em suas decisões políticas.

Controle desses valores pelas medidas de:

Ostracismo: medida judiciária para cidadão que tenha demonstrado forte influência sobre os demais, perigosamente excessiva, de afastamento da vida política (exílio) por até dez anos, sem perda de suas propriedades e condição civil. Tinha o objetivo de prevenir o surgimento da tirania.

Graphè paranómon: medida de punição judiciária para cidadão que tenha apresentado uma proposta ilegal à Assembleia. (O inverso da nossa "imunidade parlamentar".) Tal medida regulava a isegoria, o bom uso da palavra, e permitia à Assembleia reconsiderar uma decisão já tomada por ela, nesse sentido, portanto, auxiliava a Assembleia.

\section{Instituições e cargos:}

Não havia uma separação entre os diversos poderes, que hoje chamamos de executivo, legislativo, judiciário; uma mesma instituição poderia exercer funções diversas. O termo “instituição" não tem origem e uso nessa época e está sendo utilizado apenas a título didático, para tentarmos nos aproximar da organização política tal como teria ocorrido na democracia ateniense.

As "instituições" políticas, suas funções e cargos à época de Péricles seriam as seguintes:

Assembleia (ekklesía), componentes: todos os considerados cidadãos, presentes na reunião diária ao ar livre, na colina Pnyx. Função: debater e aprovar propostas e ações para a cidade (referentes a questões públicas internas e externas como obras, legislação, finanças, tributação, atos cerimoniais, guerras), inclusive as propostas de líderes políticos (como Péricles). As decisões da Assembleia ocorriam por maioria simples dos cidadãos presentes, em geral ao final do dia (a grosso modo, poderíamos dizer que possuía poderes legislativos, judiciários e executivos). O líder da Assembleia era tirado à sorte para essa função a ser exercida por um dia por qualquer cidadão presente. 
Conselho dos quinhentos (boulé), componentes: quinhentos cidadãos sendo cinquenta cidadãos tirados anualmente à sorte de cada uma das dez tribos (regiões geográficas), cargo para o qual recebiam pequena remuneração. Função: preparação administrativa dos decretos para a Assembleia e controle de tarefas executivas. Dentre esses cidadãos, uma comissão de cinquenta deles, os Prítanes, eleitos por um décimo do ano e não mais que duas vezes na vida, lideravam a execução de tais tarefas.

Tribunais populares (heliéia), componentes: 6000 cidadãos sendo seiscentos tirados à sorte de cada uma das dez tribos, função: poder judiciário e político, também expressavam a soberania popular.

Arcontes, autoridades judiciárias: um por tribo, tirados à sorte de cada uma das tribos. Havia arcontes para diferentes funções. Conforme o estudo de Arnaoutoglou (2003, p. 168), em Atenas havia nove arcontes, "um polémarkhos, um basileús, um (epônimo) arconte e os seis thesmothétai". O primeiro tratava de causas dos estrangeiros, o segundo cuidava de celebrações religiosas e presidia casos de homicídio. Os thesmothétai apresentavam denúncias de várias naturezas a serem julgadas, ratificavam acordos judiciais com outras cidades, dentre outras funções (p. 168-176). Finley (1988, p. 138) cita como função do arconte (sem especificá-lo) a seleção das peças, comédias e tragédias que seriam apresentadas em concursos nos festivais cívico-religiosos.

Estrategos, autoridades militares: um por tribo, escolhidos por eleição (poderiam ser reeleitos) de cada uma das dez tribos, eram os comandantes militares da pólis; função: magistratura que tratava da política interna e externa, de intervenções militares.

População de Atenas em torno de 430 a. C., cerca de 300 mil habitantes da Ática, conforme estimativa por Pereira (1993, p. 179), assim distribuída:

30 mil cidadãos;

100 mil escravos;

50 mil metecos (estrangeiros);

120 mil familiares.

Pereira (1993) toma esses dados de Lauffer (1968), autor a que não tivemos acesso. Tal autor teria ressaltado que os $10 \%$ dos cidadãos são um número expressivo diante do 1,5\% que toma o poder em 411 a. C., aristocratas. Ferreira (1989, p. 175) apresenta levantamento de dados semelhante. Portanto, ainda que os cidadãos não correspondam a uma extensa parte da 
população, o que se justifica por motivos histórico-políticos, há uma participação direta dos cidadãos bastante significativa nos períodos democráticos.

A obra de Finley (1988) detalha o funcionamento dessas instituições. Destacamos a seguinte descrição feita pelo autor:

\begin{abstract}
Em termos constitucionais mais convencionais, o povo não só era elegível para cargos públicos e possuía o direito de eleger administradores, mas também era seu o direito de decidir quanto a todos os assuntos políticos e o direito de julgar, constituindo-se como tribunal, todos os casos importantes civis e criminais, públicos e privados. A concentração de autoridade na Assembleia, a fragmentação e o rodízio dos cargos administrativos, a escolha por sorteio, a ausência de uma burocracia remunerada, as cortes com júri popular, tudo isso servia para evitar a criação da máquina partidária e, portanto, de uma elite política institucionalizada. A liderança era direta e pessoal; não havia lugar para marionetes medíocres manipulados por trás da cena pelos "verdadeiros" líderes. Homens como Péricles, sem dúvida, constituíam uma elite política, mas tal elite não se autoperpetuava; para conseguir ser membro dela, em primeiro lugar, era necessário desempenho público na Assembleia. $\mathrm{O}$ acesso a ela era aberto, e para permanecer como membro era preciso manter o desempenho. (FINLEY, 1988, p. 37-38).
\end{abstract}

Tal liderança direta, sem a sustentação de partidos políticos, de eleitores ou de entidades institucionalizadas, conforme Finley (1988, p. 76), constitui um traço marcante da democracia ateniense: “O ponto crítico é que não havia 'governo' no sentido moderno. Havia postos e cargos, mas nenhum deles tinha qualquer posição na Assembleia. Um homem era líder exclusivamente em função de seu status pessoal, e literalmente não oficial, na própria Assembleia". Aqui encontra-se a igualdade no poder, à qual nos referimos, a mesma oportunidade de participação nas instituições democráticas e em suas decisões políticas, o que independe de o cidadão ser pobre ou rico, líder ou liderado.

Pode-se inferir do estudo de Finley (1988), que o fator que motivava a participação dos cidadãos nas instituições democráticas atenienses era mais a vivência dos novos valores democráticos do que benefícios como o ganho financeiro: "Em meados do século V a. C., funcionários públicos, membros do Conselho e os jurados recebiam um pequeno per diem, com o valor menor do que o pagamento por dia de um pedreiro ou carpinteiro especializados" (p. 32).

O autor esclarece que a liberdade de expressão poderia ser restringida em algumas situações que a Assembleia assim deliberasse, visto que "a liberdade significava o predomínio da lei e a participação no processo decisório, não a posse de direitos inalienáveis, [...] não porque reconhecessem direitos ou alguma esfera privada fora do alcance do Estado" (FINLEY, 1988, p. 133). Importante reconhecermos, portanto, a significação de liberdade 
como situada nos limites da lei e da participação cidadã. Composto de cidadãos selecionados por sorteio (e não por qualquer espécie de formação jurídica), o júri decidia "ao fim de um dia de audiência, pela maioria dos votos obtidos em escrutínio secreto realizado à vista de todos, sem qualquer discussão [...] nos casos públicos e privados" (p. 134). Interessante observarmos tal ausência de discussão e de imparcialidade. Sobre a mistura entre funções, Finley (1988, p.134-135) destaca que:

\begin{abstract}
Em certos tipos de casos públicos, mais importantes, a própria Assembleia se reunia como se fosse um tribunal. Contudo o normal era que fossem convocados grandes júris, cujos membros eram escolhidos por sorteio dentre uma lista permanente de seis mil voluntários (no julgamento de Sócrates o número de jurados foi de quinhentos e um). [...] bastante representativos para simular o próprio dêmos em ação. [...] O papel dos júris como dêmos em miniatura envolvia uma consciência política e uma margem de ação para nós inconcebíveis, no processo de chegar a um veredicto.
\end{abstract}

Na primeira seção do presente texto, nos referimos àqueles que eram considerados cidadãos: atenienses filhos de comerciantes ou mesmo de aristocratas, camponeses, artesãos, marinheiros, etc. Eles poderiam ocupar os cargos e funções descritos acima, participando diretamente do governo. A restrição de participação direta nas instituições democráticas feita a mulheres, estrangeiros e escravos teria sido questionada já a essa época? Pereira (1993, p.182) menciona Alcidamante, um sofista discípulo de Górgias, como tendo sido um defensor da igualdade entre escravos e homens livres, da igualdade entre homens e mulheres, encontrando-se esta última também presente no Platão da República.

Deve-se reconhecer e ter a compreensão histórica de que embora os valores da isonomia, isegoria e isocracia se referissem a uma parcela da população ateniense, as legislações e as deliberações políticas democráticas tinham em vista todas as camadas da população, incluindo-se crianças, mulheres, idosos, estrangeiros, escravos. Exemplo disso pode ser visto em algumas das legislações atenienses compiladas por Arnaoutoglou (2003), como a seguinte, que trata do delito de agressão, datada do século VI a. C. e aplicada até o século IV a. C:

Se alguém cometer hýbris contra alguma pessoa, seja uma criança ou uma mulher ou um homem, livre ou escravo, ou cometer qualquer ato ilícito contra qualquer dessas pessoas, qualquer ateniense elegível que deseje pode acusa-lo aos thesmothétai... Qualquer que seja a pessoa considerada culpada, o tribunal (Heliaía) deve decidir imediatamente a pena que ela merece sofrer ou pagar. (ARNAOUTOGLOU, 2003, p. 78). 
Casos como prostituição masculina, suborno ou corrupção com promessas eram punidos com a perda dos direitos de cidadania, penalidade mais forte que aquelas previstas para roubos e homicídios, todas elas discutidas por Ilias Arnaoutoglou (2003).

Vejamos, em particular, a situação dos escravos na Atenas do século V a. C.. Quais funções ocupavam esses escravos? Ferreira (1989) faz uma descrição detalhada e interessante:

Os escravos públicos, pertença da própria pólis, além de utilizados em diversos trabalhos manuais, uns - o corpo dos archeiros citas - tinham a seu cargo o policiamento da cidade, com todo o peso que tal facto implica, inclusive autoridade sobre os cidadãos; outros, em número considerável, trabalhavam como funcionários nos diversos órgãos e edifícios da pólis: arquivos, armazéns, tesouros públicos, arsenais da marinha. (FERREIRA, 1989, p. 176).

Desse modo, contribuíam para a garantia da manutenção do governo democrático. $\mathrm{O}$ autor relata um caso de exceção, o de um escravo chamado Nicômaco que se tornou um grande consultor jurídico, motivo pelo qual recebeu estatuto de cidadão livre (nota 14, p. 176). Os escravos "não podiam possuir bens, nem constituir família legal, nem conservar os filhos juntos de si” (p. 176) do ponto de vista jurídico. A cidade garantia-lhe "o direito à vida e concedia-lhe proteção contra as violências de qualquer cidadão" (p. 177), o agressor podendo chegar à perda da posse do escravo cometia um crime contra a cidade. Finley (1988, p. 31) também relata que escravos públicos podiam ocupar a função de escriturários que faziam registros das Assembleias, "cópias de tratados e leis, lista de contribuintes inadimplentes e similares".

Quanto ao escravo que era propriedade de um cidadão particular, esclarece Ferreira (1989, p. 177):

Por outro lado, o escravo particular de modo geral não vivia ou trabalhava na casa
dos donos. Mediante o pagamento de determinada renda, poderia exercer a profissão
que lhe conviesse, viver onde quisesse ou pudesse e com quem lhe apetecesse.
Como não usava um vestuário que o diferenciasse dos homens livres, gozava de
certa liberdade. [...] colocavam-se diariamente na Ágora para serem contratados por
quem necessitasse sem diferença de salário em relação aos metecos e aos cidadãos.

As observações de Ferreira (1989) são importantes para uma compreensão do papel desempenhado pelos escravos na democracia ateniense e não pretendem fazer nem uma defesa, nem uma crítica à escravatura, reconhecendo que ela a essa época era "universalmente aceite" (p. 178). Esclarece Ferreira que a maioria dos cidadãos não possuía escravos, e a 
maioria da produção dependia não apenas do trabalho dos escravos como do trabalho dos homens livres (comerciantes, camponeses, artesãos, marinheiros, por exemplo).

O título de "meteco" era dado a estrangeiro residente "por muito tempo em território ático", como nos esclarece Nicole Loraux (1993, p. 16), recebendo então proteção jurídica. Eles não tinham direito à cidadania, mas encontravam-se integrados à cidade e autorizados a prestarem serviços a ela. Durante o século VI a. C., Atenas recebeu estrangeiros para trabalhar sobretudo como artesãos (Sólon) e como mercenários no exército público (Psístrato), de forma que à época de Clístenes esses estrangeiros já contavam com netos e bisnetos atenienses, conforme D’Ambros (2017, p. 100) que, por sua vez, já puderam ser considerados cidadãos com a reforma de Clístenes, que passa a tomar como critério de cidadania regiões geográficas conforme a localidade de nascimento e não mais a pertença a um parentesco fictício com um herói. Os metecos pagavam impostos, não podiam possuir terras, precisavam de um patrono ateniense para fazerem apelações na justiça. A abertura democrática, contudo, os integra e protege, como o fez aos escravos, pois, "ao contrário dos oligarcas, a democracia atribuía direitos aos metecos e os protegia prescrevendo-lhes deveres", segundo Nicole Loraux (1993, p. 14).

As mulheres atenienses não tinham participação direta nas instituições democráticas, como o tinham os homens. Estudos recentes, contudo, têm defendido a importância do lugar social feminino na manutenção da pólis democrática, para além do âmbito da esfera privada. Com a chamada "Lei de Péricles" (451 a. C.), que restringe a participação cidadã a filhos de pai e mãe atenienses, um status político e de alcance exterior ao espaço doméstico é dado a tal maternidade e ao comportamento feminino (ANDRADE, 2002). Quanto ao espaço público, cabia às mulheres a realização de certos rituais religiosos, a prática da tecelagem, e algumas teriam tomado para si trabalhos em tarefas agrícolas (LESSA, 2004).

A experiência da democracia direta vivenciada na Atenas dos séculos V e IV foi reconhecida pelas fontes Antigas, já mencionadas, como um modo de governo que trouxe prosperidade econômico-cultural e pacificação no interior da vida civil, mesmo em momentos em que a Assembleia deveria decidir os rumos de uma guerra, pois os ideais de líderes políticos (como o próprio Péricles) e o voto da maioria eram debatidos e respeitados. Contudo, a fragilidade de decisões da maioria em situações significativas (como as de guerra) foi comentada já àquela época por Tucídides e objeto de crítica por Platão. Tal fragilidade deve-se à diversidade de interesses envolvidos nas propostas de figuras políticas mais proeminentes (demagogos), bem como ao desconhecimento de todos os fatores envolvidos em 
certas situações objeto destas propostas. Isso teria ocorrido na votação (415 a. C.) da expedição à Sicília - que fracassa - situação em que os cidadãos teriam desconhecido os fatores geográficos, o tamanho da ilha e de sua população, embora desejassem tomar parte no exército ou na marinha, segundo Finley (1988, p. 33; 35; 56), que esclarece: "Ele (Tucídides) conta que Alcibíades foi o orador que mais pressionou na Assembleia por diversas razões: desejava derrotar Nícias, era pessoalmente ambicioso e esperava obter fama e riqueza com seu posto de general na campanha [...]” (p. 57). A essa altura, Péricles já havia sido morto pela peste. Quanto à crítica à forma pura de democracia feita por Platão, abordaremos na próxima seção.

O término do regime democrático em Atenas ocorre com o domínio da Macedônia sobre a Grécia, por Filipe, na batalha de Queroneia em 338 a. C. (FINLEY, 1988, p. 96; MCWHORTER, 1951, p. 298), quando Atenas perde sua independência e liberdade. Nos limites do presente estudo, não nos deteremos à compreensão da democracia ateniense no século IV a. C., o que exige o estudo de suas fontes e sua compreensão histórica.

\section{O OLHAR DA FILOSOFIA DE PLATÃo SOBRE A DEMOCRACIA (REPÚBLICA, LEIS)}

Platão faz referência à democracia em alguns de seus diálogos (como a Apologia, o Górgias, a República, as Leis). A boa mistura entre elementos saudáveis da democracia com elementos saudáveis da monarquia é proposta nas Leis (diálogo escrito nos dez últimos anos de vida de Platão). A constituição política para a cidade projetada nas Leis conjuga elementos que são inerentes à democracia e à monarquia, "a liberdade e a amizade, com sabedoria" (III 693d7-e1). Platão volta a defender, como na República VIII, que uma excessiva liberdade não conduz à situação de soberania (ser mestre /kýrios) de um povo e à adesão consentida das leis, mas a uma obediência cega a leis insensatas, ou seja, à "escravidão" consentida em relação às leis (698b, 700a). Assim, a cidade de Magnésia será regida pela medida /métron (689a-c, 698b1), pela inteligência /noûn (701d8), pelo discernimento e pela temperança (712 a), pelas melhores leis e para a paz.

A boa mistura entre sabedoria e liberdade encontra-se presente na relação entre as três instituições da cidade em palavras, proposta em As Leis: a Assembleia dos cidadãos, o Conselho com tarefas administrativas, do qual participam classes censitárias que elegem cada uma - 90 conselheiros de cada uma das doze pritanias, e um Conselho de velhos 
guardiões das leis que tem tanto a função de elaborar e fundar a legislação, como a de aplicála por meio dos vários tipos de magistraturas (pedagógica, militar, religiosa, jurídica, etc.), daí a necessidade de possuírem educação filosófica ${ }^{13}$. Tal proposta coloca o leitor dos diálogos em dúvida sobre porque a democracia, isoladamente, é objeto de crítica no livro VIII da República.

Devemos compreender a crítica à forma pura de democracia presente em República VIII à luz de pressupostos da filosofia platônica, que podem ser identificados quando aprofundamos o estudo da íntima relação que Platão estabelece, nesse diálogo e em outros, entre psicologia, ética e política ${ }^{14}$. As relações de poder entre diferentes classes na cidade são consideradas análogas àquelas que ocorrem entre os diferentes elementos da psykhé humana. A igualdade perante à lei, no poder, no falar constitui o pilar do regime democrático sem mistura. Platão mostra-se um crítico de tal pretensão à igualdade, pois ressalta as diferenças entre as classes da cidade, bem como as diferenças entre as chamadas partes (ou gêneros) da alma individual (o racional, o irascível, o apetitivo). A democracia é referida, na República VIII, como regime político conflituoso, tanto no âmbito do indivíduo (no interior da psykhé humana) como no âmbito da cidade (tensão entre os vários interesses das várias classes da cidade), por isso não conduz à paz e à realização da virtude da justiça, o que ocorreria apenas na alma do rei-filósofo e na cidade reta (paradigmas traçados na República).

Em República VIII (555b), a análise feita pelo Sócrates platônico a respeito da origem e do modo de estruturação política dos regimes políticos (monarquia, timocracia, oligarquia, democracia, tirania), o regime democrático é retratado como aquele que surge a partir do exacerbamento daquilo que caracteriza o oligárquico, do querer ser o mais rico possível. Conforme tal genealogia teorizada por Platão, o crescimento da pobreza, e mesmo a redução à penúria de alguns nobres, fatores que são gerados por essa ambição, levam a cidade a um conflito interno. Os governados reconhecem que é pela sua covardia que prosperam os ricos e que se deixam explorar por aqueles que "nada valem" (555d-e). Com ou sem auxílio do exterior, tal cidade entra em guerra civil, e a vitória dos pobres faz surgir o regime democrático.

\footnotetext{
${ }^{13}$ A respeito, ver os comentários dos tradutores franceses Luc Brisson e Jean-François Pradeau na edição de 2006 pela Flammarion. Quanto à magistratura jurídica, os guardiões das leis, com idade mínima de 50 anos, seriam eleitos em votação pela Assembleia e, após exame de mérito e educação (V 751d), ocupariam a magistratura até completarem os 70 anos. Eles cumpririam funções legislativas e judiciárias, incluindo delimitação de corte para julgamento de crimes contra a cidade ou de certas causas privadas. Sobre a educação do cidadão e do legislador nas Leis, bem como sobre a reformulação feita por Platão do paradigma do mal involuntário em Leis IX por meio da retomada da teoria da tripartição da alma nas Leis, ver Reis (2010, parte 2). ${ }^{14} \mathrm{O}$ que realizamos em Reis (2009).
} 
O direito de se fazer o que se preferir, de organizar a própria vida, a variedade de caracteres presentes nas constituições democráticas, caracterizam o novo regime. Entretanto, não haveria nele a preocupação com a preparação para a prática política, com a formação do homem bom lagathós (558b). É uma forma de governo “aprazível /hedeîa, anárquica, variegada, e que reparte a sua igualdade do mesmo modo pelo que é igual e pelo que é desigual" (558c, grifo nosso).

O combate na alma do homem democrático ocorre porque seus apetites multiplicamse e tomam força por encontrar-se sua alma vazia de conhecimentos/mathemáton, de belas ocupações lepitedeumáton kalôn e de discursos verdadeiros /lógon alethôn "que são os melhores sentinelas e guardiões nos espíritos amados pelos deuses" (560b, com modificações). Ocupam seu lugar discursos e opiniões falsos e presunçosos, capazes de impedir a entrada de um socorro exterior e de vencerem tal combate, passando assim a chamar "imbecilidade à vergonha... covardia à temperança", designando "a insolência por boa educação, a anarquia por liberdade, a prodigalidade por generosidade, a desfaçatez por coragem" (560d; 560e).

Tal homem passa a dar o mesmo valor a quaisquer dos apetites, cultivando tanto os prazeres necessários quanto os não necessários. Ele não distingue os apetites belos /kalôn e bons /agathôn daqueles perversos, maus /ponerôn, nem que se deve "cultivar e honrar os primeiros, e castigar /koládzein e escravizar /douloûsthai os segundos" (561c), considera todos os prazeres semelhantes /homoías e dever honrá-los por igual lex ísou. Desse modo, entrega o governo de si mesmo ao primeiro prazer que se lhe apresentar, "como se fosse determinado pela sorte, até se saciar, e depois a outro, sem menosprezar nenhum, mas cultivando-os por igual” (561b). Passará cada dia a buscar satisfazer ora um ora outro apetite, em uma vida carente de ordem/táxis e de necessidade lanágke, acreditando ser esta "doce, livre e bem-aventurada" (561d), a vida de um amigo da igualdade /isonomikô̂.

A descrição da estruturação política da psykhé do democrata, no livro VIII, permitenos deduzir que não se trata de uma alma pacificada, justa, pois ela vivencia um constante estado de conflito entre os apetites não-necessários (aqueles excessivos) e a potência da parte irascível da alma, ou seja, o poder para a contenção de apetites e para a ação do temor respeitoso, da crítica, por parte do par irascível-racional, configurando-se um estado interno de conflito de poder entre os gêneros apetitivo e irascível da alma.

O homem democrático tudo quer, homem da multiplicidade e da descontinuidade. Esse estado de alma impede que a alma como um todo ultrapasse as constantes demandas do 
gênero apetitivo e que se lance, como um todo, para a busca da verdade. Essas são as razões apresentadas por Platão no livro IX para criticar um regime democrático puro (sem mistura), pois esse é o distanciamento em que se encontra a alma do democrata em relação à alma do governante justo, o paradigma do rei-filósofo. A alma do democrata e a cidade democrática estão a um passo da tirania.

A tirania surgiria de uma alteração da democracia, da ambição pelo valor da liberdade. Quando se está embriagado dela, exige-se sua abundância e seu excesso conduz à anarquia, seja no domínio da cidade ou dos homens (562c-d). Há uma inversão das relações entre governantes e governados, na qual os governados buscam dominar aqueles que deveriam exercer o poder, isto é, dos subordinados em relação aos chefes, dos filhos aos pais, dos estrangeiros ou metecos aos cidadãos, dos discípulos em relação ao mestre, dos jovens aos velhos, dos escravos aos senhores. Ocorre que as almas daqueles que devem ser dirigidos não suportam um mínimo de submissão e "acabam por não se importar nada com leis escritas ou não escritas" (563d). O excesso de liberdade leva a uma mudança radical em sentido oposto, ou seja, à escravidão: “A liberdade em excesso, portanto, não conduz a mais nada que não seja a escravatura em excesso, quer para o indivíduo /idiótei, quer para a cidade /pólei." (564a, grifo nosso).

$\mathrm{Na}$ origem do homem tirânico encontram-se os apetites não necessários e os selvagens. O filho do democrata é levado ao desprezo das leis por aqueles que consideram tal desprezo ser a mais suprema liberdade, criando nele uma espécie de "zângão enorme e alado", ou seja, um amor a estes apetites "ociosos" (573a). Alimentados ao máximo, levam a alma ao delírio como se estivesse picada por tal zângão, matando e expulsando apetites e opiniões honestos que até então pudessem existir nesse jovem, assim como a temperança /sophrosýne (573b). Havendo na cidade tais pessoas em grande número e, “com a cumplicidade e estupidez do povo" (575c-d), geram um tirano, capaz de escravizar então a pátria (575d, também 577c). O tirano constitui o mais perverso dos homens, o mais desgraçado e o mais infeliz (576c, também 578b). O que também ocorre à cidade governada por um tirano.

O paradigma platônico oposto ao do tirano é o do rei-filósofo, cuja alma e governo são justos, dada a conquista da posse da virtude, pela educação dos três gêneros de sua alma (seu autogoverno pelo elemento racional educado pela dialética). Em Platão, a escravidão é o domínio do pior sobre o melhor por natureza, o que ocorre na tirania e na alma tirânica, e a liberdade corresponde ao oposto, ao comando do melhor, em virtude, em ciência, o que ocorre na realeza e na alma filosófica. A condição para a liberdade e para a ação justa é, portanto, a 
reta educação da unidade corpo-alma, sobretudo por meio do exercício da dialética. Guiar-se pelo lógos é ser livre.

Compreendemos que Platão mostra-se, nesse ponto, não como um crítico radical da igualdade ou da liberdade, mas como um filósofo da diferença (que distingue teoricamente, para melhor compreender) e instaurador de uma interpretação genuína do conceito de liberdade.

Na análise do livro VIII da República, Newton Bignotto (1998) nos lembra que a relação entre democracia e tirania ocorreu no plano histórico e pôde ser pensada no plano teórico por filósofos como Platão. A consolidação da democracia no século V a. C. ocorreu como regime político erguido em oposição à tirania de Psístrato e seus filhos. Nas passagens da República de Platão, a democracia pura é um regime conflitivo, capaz de produzir a tirania. A tirania, contudo, é teorizada não apenas como resultado de tal decadência, mas como "o ideal negativo da vida política", por ser modelo da "destruição da vida pública pela lógica dos desejos" (BIGNOTTO, 1998, p. 135).

\section{CONSIDERAÇÕES FINAIS}

Convidamos o leitor a não julgar as fontes e a experiência democrática grega clássica, bem como as considerações da filosofia platônica a respeito da forma pura de democracia, e sim a buscar compreendê-las em seu contexto histórico e em sua significação própria, conforme aqueles que protagonizaram esse momento histórico.

Não vamos fazer uma síntese de cada seção exposta no presente texto, o que seria extenso e desnecessário. Devemos nos colocar sempre dispostos ao aprofundamento do tema, à revisão bibliográfica e à tentativa de recompor o complexo quadro constituído pela democracia grega, em especial pela democracia ateniense.

A pergunta que não quer calar, sobre o que podemos retirar de útil, para os tempos atuais, da experiência democrática grega, mostra-se equivocada. Pois, como buscamos mostrar, somente em seu contexto histórico (épocas e locais) a democracia grega encontra o sentido de sua existência. A pergunta pela utilidade revela mais a nossa angústia contemporânea, a nossa tentativa de remediar impasses de difícil solução (como os do nosso Brasil de 2018) de modo a permitir a realização saudável de um regime democrático que, contudo, não é o mesmo em diferentes locais e épocas. Há também um impedimento estrutural para tal comparação que se refere à forma representativa que as democracias 
modernas adquirem, além de seus detalhamentos históricos específicos levados em conta pela literatura sobre democracia moderna.

Ao mesmo tempo, nos vem à mente Górgias (1980) em seu "Elogio a Helena", alertando seus ouvintes de que o mesmo instrumento que pode emocionar, enganar, envenenar as almas, pode questionar, beneficiar, encantar as almas, pois "a palavra é um poderoso soberano, que, com um pequeníssimo e muito invisível corpo, realiza empreendimentos absolutamente divinos". O caráter persuasivo da palavra, bem como sua insuficiência em dizer "o que é", fazem dela instrumento de poder, de ação política. Como também o reconheceu Platão em sua obra, seja como remédio, seja como veneno, tudo depende de "como" e "para que" a utilizamos. A humildade e o fim ético no uso público desse poderoso corpo, por cidadãos ou por seus representantes, inclusive como uma das formas de resistência a opressões, talvez sejam a nossa "luz no fim do túnel".

\section{REFERÊNCIAS}

ANDRADE, Marta Mega de. O público, o privado e o espaço doméstico. In: ANDRADE, Marta Mega de. A vida comum: espaço, cotidiano e cidade na Atenas Clássica. Rio de Janeiro: DP\&A Editora, 2002. Cap. 3, p. 93-114.

ARISTÓTELES. Política. Tradução de Nestor Silveira. São Paulo: Folha de São Paulo, 2010. (Coleção Folha; v.11).

ARISTÓTELES. Ética a Nicômaco. Tradução de Leonel Vallandro e Gerd Bornheim. S.P.: Edições Victor Civita, 1984. (Os Pensadores).

ARNAOUTOGLOU, Ilias. Leis da Grécia Antiga. Tradução de Ordep Trindade Serra, Rosiléa Pizarro Carnelós. São Paulo: Odysseus, 2003.

BAILLY, Anatole. Le Grand Dictionnaire Grec Français. 4. éd. Paris: Hachette, 2000.

BIGNOTTO, Newton. O tirano e a cidade. São Paulo: Discurso Editorial, 1998. (Coleção Clássicos \& Comentadores).

DAHL, Robert A. Onde surgiu e como se desenvolveu a democracia? Uma breve história. In: DAHL, Robert A. Sobre a democracia. Tradução de Beatriz Sidou. Brasília: Editora Universidade de Brasília, 2001. Cap. 2, p.17-35.

DAMBRÓS, Bruno Rodrigo. A reorganização territorial Ática sob Clístenes: a democracia como enfraquecimento dos poderes parental-aristocráticos. Revista Hélade, Rio de Janeiro: UFF, a.3, v.3, p. 96-106, 2017.

DURANDO, Furio. A Grécia Antiga. Tradução de Carlos Nougué. Barcelona: Ediciones Folio S.A., 2005. (Coleção Grandes Civilizações do Passado, v.1). 
FERREIRA, José Ribeiro. Atenas, uma democracia? Conferência realizada na Faculdade de Letras do Porto em 17/04/1989. Disponível em:

<www.ler.letras.up.pt/uploads/ficheiros/2597>. Acesso em: 02 fev. 2018.

FINLEY, Moses I. Democracia antiga e moderna. Tradução de Waldéa Barcellos, Sandra Bedran. Rio de Janeiro: Edições Graal Ltda, 1988.

HANSEN, Mogens Herman. The Tradition of the Athenian Democracy A. D. 1750-1990.

Greece \& Rome, Vol. xxxix, No. 1, April 1992, p.14-30. Published by: Cambridge University Press on behalf of The Classical Association Stable. URL:

<http://www.jstor.org/stable/643118>. Acesso em: 07 mar. 2018.

LESSA, Fábio de Souza. O feminino em Atenas. Rio de Janeiro: Mauad Editora, 2004.

LORAUX, Nicole. A democracia em confronto com o estrangeiro (Atenas, Paris). In:

CASSIN, Barbara et al. Gregos, bárbaros, estrangeiros. A cidade e seus outros. Tradução de Ana Lúcia de Oliveira e Lúcia Cláudia Leitão. Rio de Janeiro: Edições 34, 1993, p. 11-33.

MCWHORTER, Robert L. The Athenian Democracy. The Georgia Review, v. 5, n. 3 (FALL - 1951), p. 290-299 Published by: Georgia Review Stable. URL:

<http://www.jstor.org/stable/41396113>. Acesso em: 07 mar. 2018.

PEIXOTO, Miriam C. D. Reabilitando os sofistas. Revista da Fundação Educacional Monsenhor Messias, Sete Lagoas, v.1, n. 1, 1994, p. 39-53.

PEREIRA, M. H. da Rocha. O nascimento da democracia. In: PEREIRA, M. H. R., Estudos de história da cultura clássica. Cultura grega (v.1). 7. ed. Lisboa: Fundação Calouste Gulbenkian, 1993. Parte 2 do Cap. IV, p. 177-187.

GÓRGIAS, Elogio a Helena. In: GÓRGIAS. Fragmentos y testimonios. Tradução de Eloísa Cerdán del Lama e Antônio Suárez Abreu. Buenos Aires: Aguilar, 1980, p. 85-92. Disponível em: <http://doczz.com.br/doc/415266/elogio-a-elena>. Acesso em: 01 fev. 2018.

PLATÃO. República. Tradução de M. H. da Rocha Pereira. 7. ed. Lisboa: Fundação Calouste Goubenkian, 1993.

PLATÃO. Politeias Platonis Opera - T.IV tetralogiam VIII continens [insunt Politia, Timaeo et Critia], recognovit brevique adnotatione critica instruxit Ioannes Burnet. Oxford: Oxford Clarendon Press, 1902.

PLATÃO. As Leis. Tradução e Comentários de Edson Bini. Bauru, SP: EDIPRO, 1999.

PLATON. Les Lois. Traduction, introduction et notes par Luc Brisson et Jean-François Pradeau. T.I-II. Paris: GF-Flammarion, 2006.

REIS, M.D.; OLIVEIRA, R. de Abreu. O Sócrates platônico da Apologia. Contexto humano, ético-político e filosófico. Relatório de Pesquisa apresentado à Pró-reitora de Pesquisa e de Pós-Graduação da PUC Minas, Belo Horizonte, dez. 2009. 
REIS, M. D. Psicologia, ética e política. A tripartição da psykhé na República de Platão. São Paulo: Edições Loyola, 2009. (Coleção FAJE).

REIS, M. D. Virtude e vício. Tripartição e unidade da psykhé no Timeu e nas Leis de Platão. Rio de Janeiro: Editora 7 Letras, 2010.

SARTORI, Giovanni. A democracia grega e a democracia moderna. In: SARTORI, Giovanni. A teoria da democracia revisitada. Edição de Irene Catarina Nigro. V.2: As Questões Clássicas. São Paulo: Editora Ática, 1994. Cap. 10, p. 34-58. 